\title{
Do conto ao microconto: 240 anos de Porto Alegre na visão dos alunos ${ }^{1}$
}

\author{
Andrea Esther Anocibar \\ Clarissa Leonhardt Borges*
}

Figura 1: Blog dos alunos da turma 91 desenvolvido nas aulas de Produção Textual.

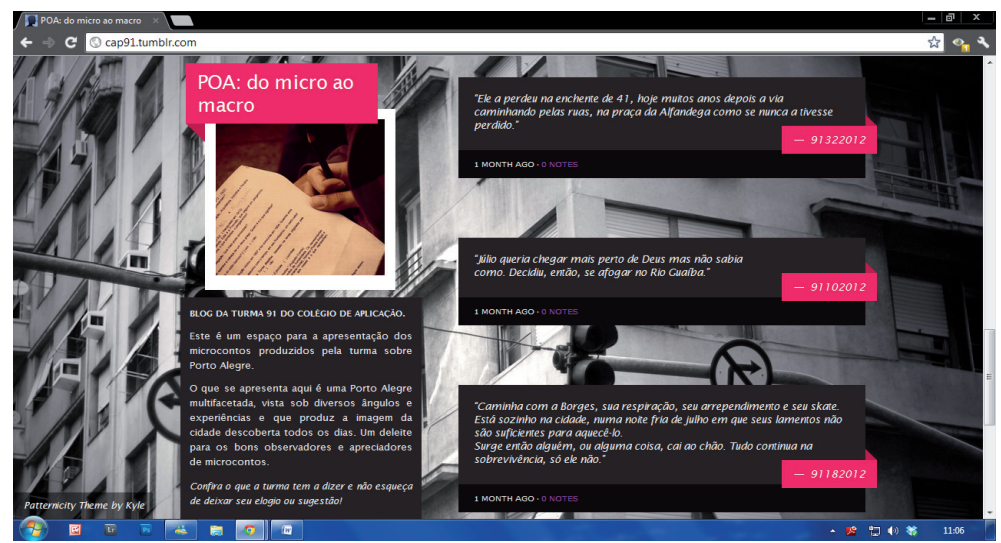

* Acadêmica do curso de Letras da UFRGS. E-mail: andrea_anocibar@yahoo.com. br

* Acadêmica do curso de Letras da UFRGS. E-mail: clarissalborges@gmail.com

1 O projeto de Estágio de Docência em Língua Portuguesa intitulado Do conto ao microconto: 240 anos de Porto Alegre na visão dos alunos proporcionou uma abordagem transdisciplinar sobre a história, a arquitetura e a literatura porto-alegrense. $\mathrm{O}$ objetivo foi mostrar de que forma a cidade é retratada pelos alunos da turma 91 . O crescente contato com a Internet e com as redes sociais foi o ponto de partida deste projeto, que priorizou a produção textual com um leitor real e instantâneo. Para tanto, foram escritos microcontos, posteriormente publicados no endereço http:// cap91.tumblr.com/, disponível para visitação. O projeto foi desenvolvido entre os meses de abril e junho de 2012 pelas estagiárias Andrea Esther Anocibar e Clarissa Leonhardt Borges. Professor responsável: Tadeu Rossato Bisognin. 
"Godofreda e um crítico gastronômico estavam almoçando simultaneamente no Mercado. Ele sentiu um gosto ruim no bife. Godofreda precisa ir ao banheiro, mas é surpreendida no caminho e degolada. Rapidamente a guardam no freezer da loja.”

Giulia Conde de Albite Acerbi

"Ele a perdeu na enchente de 41 , hoje muitos anos depois a via caminhando pelas ruas, na praça da Alfandega como se nunca a tivesse perdido."

Raphaela Dorneles Camargo de Souza

"Júlio queria chegar mais perto de Deus mas não sabia como. Decidiu, então, se afogar no Rio Guaíba.”

Cristofer de Oliveira Vicente

"Caminha com a Borges, sua respiração, seu arrependimento e seu skate. Está sozinho na cidade, numa noite fria de julho em que seus lamentos não são suficientes para aquecê-lo. Surge então alguém, ou alguma coisa, cai ao chão. Tudo continua na sobrevivência, só ele não.”

Isabela Balconi Sydow 